\title{
Infusion-related thrombogenesis by liver- derived mesenchymal stem cells controlled by anticoagulant drugs in 11 patients with liver-based metabolic disorders
}

\author{
Louise C. F. Coppin ${ }^{{ }^{*} \mathbb{D}}$, Françoise Smets ${ }^{1}$, Jérome Ambroise², Etienne E. M. Sokal ${ }^{1}$ and Xavier Stéphenne ${ }^{1}$
}

\begin{abstract}
Background: Mesenchymal stem cell (MSC) transplantation is a fast-developing therapy in regenerative medicine. However, some concerns have been raised regarding their safety and the infusion-related pro-coagulant activity. The aim of this study is to analyze the induced thrombogenic risk and the safety of adding anticoagulants during intraportal infusions of liver-derived MSCs (HepaStem), in patients with Crigler-Najjar (CN) and urea cycle disorders (UCD).

Methods: Eleven patients (6 CN and 5 UCD patients) were included in this partially randomized phase $1 / 2$ study. Three cell doses of HepaStem were investigated: low $\left(12.5 \times 10^{6}\right.$ cells $\left./ \mathrm{kg}\right)$, intermediate $\left(50 \times 10^{6} \mathrm{cell} / \mathrm{sg}\right)$, and high doses $\left(200 \times 10^{6} \mathrm{cell} / \mathrm{sg}\right)$. A combination of anticoagulants, heparin $\left(10 \mathrm{I} . \mathrm{U} . / 5 \times 10^{6} \mathrm{cells}\right)$, and bivalirudin $(1.75 \mathrm{mg} /$ $\mathrm{kg} / \mathrm{h}$ ) were added during cell infusions. The infusion-related thrombogenic risk and anticoagulation were evaluated by clinical monitoring, blood sampling (platelet and D-dimer levels, activated clotting time, etc.) and liver Doppler ultrasound. Mixed effects linear regression models were used to assess statistically significant differences.

Results: One patient presented a thrombogenic event such as a partial portal vein thrombus after 6 infusions. Minor adverse effects such as petechiae, epistaxis, and cutaneous hemorrhage at the site of catheter placement were observed in four patients. A significant decrease in platelet and increase in D-dimer levels were observed at the end of the infusion cycle, normalizing spontaneously after 7 days. No significant and clinically relevant increase in portal vein pressure could be observed once the infusion cycle was completed.

Conclusions: The safety- and the infusion-related pro-coagulant activity remains a concern in MSC transplantation. In our study, a combination of heparin and bivalirudin was added to prevent the thrombogenic risk induced by HepaStem infusions in 11 patients. A significant decrease in platelet and increase in D-dimer levels were observed, suggesting the activation of coagulation in these patients; however, this was spontaneously reversible in time. We can conclude that adding this combination of anticoagulants is safe and limits infusion-related thrombogenesis to subclinical signs in most of the patients.
\end{abstract}

Trial registration: ClinicalTrials.gov identifier: NCT01765283-January 10, 2013

Keywords: Mesenchymal stem cells, Cell therapy, Blood coagulation, Clinical trial, Liver diseases

\footnotetext{
* Correspondence: coppinlouise@gmail.com

${ }^{1}$ Service de Gastro-Entérologie et Hépatologie Pédiatrique, Cliniques

Universitaires Saint-Luc, Université Catholique de Louvain, Av Hippocrate 10,

B-1200 Brussels, Belgium

Full list of author information is available at the end of the article
}

(c) The Author(s). 2020 Open Access This article is distributed under the terms of the Creative Commons Attribution 4.0 International License (http://creativecommons.org/licenses/by/4.0/), which permits unrestricted use, distribution, and reproduction in any medium, provided you give appropriate credit to the original author(s) and the source, provide a link to the Creative Commons license, and indicate if changes were made. The Creative Commons Public Domain Dedication waiver (http://creativecommons.org/publicdomain/zero/1.0/) applies to the data made available in this article, unless otherwise stated. 


\section{Background}

Orthotopic liver transplantation (OLT) is still the current treatment of choice for patients presenting endstage liver disease or liver-based inherited metabolic diseases, when conservative treatment cannot maintain a sufficient liver function or quality of life. However, due to organ shortage, the growing demand for organs and the substantial risks of morbidity and mortality linked to immunosuppression and surgery, other treatments, such as cell-based therapy, are being developed. In metabolic patients, the aim is to provide the missing specific liver functions and prevent the metabolic decompensation and related side effects. Hepatocyte transplantation can be an alternative treatment for liver-based metabolic conditions [1-7]. However, this treatment is limited due to the inability of hepatocytes to proliferate in vitro, due to the metabolic damages induced by cryopreservation and to organ shortage as well [8-10]. Other cell sources, such as mesenchymal stem cells (MSCs), are currently under evaluation in numerous clinical trials. Unlike hepatocytes, MSCs can be isolated and expanded efficiently in vitro. They are undifferentiated cells that can differentiate after transplantation, under the influence of local environmental signals, into cells expressing the appropriate phenotype [11]. Patients presenting urea cycle disorders (UCDs) and Crigler-Najjar (CN) syndrome are good candidates for MSC transplantation, because their current treatments are heavy, only supportive, and impose a real burden on the patients and their family.

Previous studies [12] showed that liver-derived MSCs or HepaStem, like other MSCs [13-16], express a procoagulant activity (PCA) that cannot be inhibited using one anticoagulant drug individually. Due to the overexpression of tissue factor (TF), MSCs in contact with blood activate coagulation and induce a thrombogenic risk in the transplanted patients. Several infusion-related thrombi have been reported in literature [17-22]. Bennet et al. [23] were the first to describe a thrombo-inflammatory reaction when pancreatic islets, expressing TF, were in contact with blood, which they called instant blood-mediated inflammatory reaction (IBMIR). IBMIR has been described as a dual activation of the coagulation and the complement pathway by islets or cells bearing TF. Transplanted cells are rapidly encapsulated in a blood clot, with infiltration by activated polymorphonuclears (PMNs), causing early cell destruction, leading to poor cell engraftment [12, 24-27].

Nonetheless, the procoagulant activity of HepaStem can be limited, in in vitro models, using a combination of anticoagulants, including an antithrombin activator (heparin) and thrombin inhibitor (bivalirudin) [12]. The objective of this study is to analyze the thrombogenic risk induced by HepaStem infusion and the safety of the use of this anticoagulant cocktail in $\mathrm{CN}$ and UCD patients.

\section{Methods}

\section{Health authorities and ethical review}

Ethical approval to report this case series was obtained from Belgian regulatory authorities and the ethical committee (2011/04OCT/388). All procedures in this study were conducted in accordance with the European Medicines Agency's (EMA) pediatric committee (EudraCT number: 2011-004074-28) and conducted according to the 2000 revised principles of the Declaration of Helsinki (ClinicalTrials.gov identifier: NCT01765283). Written informed consent was obtained from the patient or a legally authorized representative(s) for anonymized patient information to participate in this study.

\section{Study population}

The data we developed hereafter are part of a multicentric phase 1-2 clinical trial which described the therapeutic effects of the cell therapy [28]. Included patients had a confirmed diagnosis of Crigler-Najjar (CN) syndrome (I or II) or urea cycle disorder (UCD) (ornithine transcarbamylase (OTC) deficiency or arginase deficiency) by genetic mutation analysis. General inclusion criteria included patient and/or legal representative providing written informed consent, negative pregnancy test for a female subject with childbearing potential, and patency of the portal vein and branches. For $\mathrm{CN}$ patients, specific inclusion criteria included the diagnosis of $\mathrm{CN}$ poorly nonresponsive to phenobarbital treatment. Specific inclusion criteria for UCD patients included a disease of such severity (e.g., poor protein tolerance and recurrent hyperammonemic crises despite maximal conservative metabolic treatment) to warrant liver transplantation or alternatives. Major exclusion criteria included acute liver failure, clinical or radiological evidence of liver fibrosis or cirrhosis, known medical or family history of coagulopathy, and the presence of a thrombosis of the portal vein or persisting impairment of anterograde portal blood flow.

We included 11 patients (6 $\mathrm{CN}$ and $5 \mathrm{UCD}$ patients) in this prospective, open-label, partially randomized, dose-escalation phase $1 / 2$ study (see Table 1 , and consort flow diagram in Additional file 1) (ClinicalTrials.gov Identifier: NCT01765283). For ethical reasons, the placebo effect was not studied. Three cell doses were investigated: low $(12.5 \times 10$ cells $/ \mathrm{kg})$, intermediate $\left(50 \times 10^{6}\right.$ cells $/ \mathrm{kg})$, and high $\left(200 \times 10^{6}\right.$ cells $\left./ \mathrm{kg}\right)\left(4 \times 10^{9}\right.$ maximum total cell count). Cells were administered as one cycle of one or several infusions, depending on the assigned cell dose and the patient's body weight, with a maximum of $250-500 \times 10^{6}$ cells. Thereafter, an interval of 2-6h was taken before reinfusion of the next cells.

\section{Cell preparations}

Liver-derived mesenchymal stem cells or HepaStem were obtained from healthy human donor livers $(n=3)$ 
Table 1 Population

\begin{tabular}{ll}
\hline & Number of patients \\
\hline Infused patients & 11 \\
Crigler-Najjar & 6 \\
Type 1 & 5 \\
Type 2 & 1 \\
Urea cycle defect & 5 \\
OTC deficiency & 4 \\
Arginase deficiency & 1 \\
Sex & \\
Female & 7 \\
Male & 4 \\
Age at infusion & $0.9-16.25$ year(s) \\
Patients per cell dosage & \\
$12.5 \times 10^{6} / \mathrm{kg}$ & 4 \\
$50 \times 10^{6} / \mathrm{kg}$ & 2 \\
$200 \times 10^{6} / \mathrm{kg}$ & 5 \\
Total number of infusions & $1-10$ \\
Total number of days of infusions & $1-4$ \\
Completed infusion cycles & 7 \\
\hline
\end{tabular}

as previously described [29]. No organs from executed prisoners were used. Cells were purified, characterized, and expanded in vitro for five successive passages, then harvested, cryopreserved in CryoStor-10 (10\% dimethyl sulfoxide (DMSO)), and stored in liquid nitrogen. Before use, the cells were thawed and washed in human albumin solution $5 \%$ to remove DMSO. Then, they were conditioned in bags of $50 \mathrm{ml}$ in an infusion solution (human albumin 5\%, heparin 10 I.U./ml (Heparin Leo ${ }^{\circ}$, Leo Pharma, Ballerup, Denmark)) at a concentration of $5 \times$ $10^{6}$ cells per milliliter. Final heparin concentration was 10 I.U. per $5 \times 10^{6}$ cells; therefore, patients received respectively between 25 and 400 I.U. of heparin $/ \mathrm{kg}$ during the whole infusion cycle depending on the cell dose used, with a maximum of 1000 I.U. of heparin per infusion. The infused cells presented a viability of $60-80 \%$ at the trypan blue test. Each patient received cells from the same donor.

\section{Infusion protocol}

Cells were infused intravenously through a percutaneous transhepatic catheter inserted into the portal vein under radio guidance or via catheter inserted surgically in an affluent of the portal vein. Before each infusion, an ultrasound was performed to assure the catheter was in place and permeable. Surveillance of the portal-vein pressure was maintained throughout the entire infusion procedure and after the cycle of infusions. The flow rate of infusion was kept at $0.5-2 \mathrm{ml} / \mathrm{min}$.

\section{Concomitant therapy}

Before and during the infusion period, a prophylactic anticoagulation treatment, bivalirudin (Angiox $^{\circ}$, The Medicines Company, Abingdon, UK), was concomitantly administered to all the patients. The same treatment protocol was used for percutaneous coronary interventions. Bivalirudin was started $15 \mathrm{~min}$ ahead of the cell infusion to provide a loading dose. Through the infusion, we administered a dose of $1.75 \mathrm{mg} / \mathrm{kg} / \mathrm{h}$ that was reduced to $0.25 \mathrm{mg} / \mathrm{kg} / \mathrm{h}$ at the end of the cell infusion, until re-start of the next cell infusion, for a maximum of $2 \mathrm{~h}$ (if next infusion was scheduled). Immunosuppressive treatment was given to each patient through the entire study duration. A single bolus of Solumedrol (Solumedrol $^{\circ}$, Pfizer, New York City, NY, USA) $(2 \mathrm{mg} / \mathrm{kg})$ a day was given before the infusion. Basiliximab (Simulect ${ }^{\circ}$, Novartis Pharma, Basel, Switzerland) was given on day 0 (day of the first infusion) and day $4(5 \mathrm{mg} /$ day for $<15 \mathrm{~kg}$ body weight, $10 \mathrm{mg}$ for $15-35 \mathrm{~kg}, 20 \mathrm{mg}$ for > $35 \mathrm{~kg}$ ). Tacrolimus (Prograft ${ }^{\circ}$, Astellas Pharma, Tokyo, Japan) therapy was started at $0.3 \mathrm{mg} / \mathrm{kg}$, with dose adjustments to reach as quickly as possible target blood levels of $10 \pm 2 \mathrm{ng} / \mathrm{ml}$. Antibiotics were administered before the placement of the catheter to prevent postoperative infections according to institutional guidelines. They also receive chemoprophylactic medication to prevent opportunistic infections (antiviral, antimicrobial) according to current recommendations of chemoprophylaxis after liver transplantation.

\section{Safety and monitoring of the patient}

Vital signs (heart rate, blood pressure, oxygen saturation, and respiratory rate) were monitored through the entire infusion. The monitoring of the anticoagulation therapy was done with the measurement of activated clotting time (ACT) and $\mathrm{ROTEM}^{\circ}$ delta analyzer (Pentapharm, Munich, Germany) at selected times. ACT was measured before, and every $30 \mathrm{~min}$ during and after the cell infusion. Cell infusion was started once ACT levels were > $200 \mathrm{~s}$ and kept at values between 200 and $350 \mathrm{~s}$ during the cell infusion. If values exceeded $350 \mathrm{~s}$, bivalirudin was reduced from 1.75 to $0.25 \mathrm{mg} / \mathrm{kg} / \mathrm{h}$ with ACT measurements every $15 \mathrm{~min}$ until the value(s) were between 200 and $350 \mathrm{~s}$. D-dimers (normal values $<500 \mathrm{ng} / \mathrm{ml}$ ) were measured after the catheter placement, prior to and after the infusions, and the morning after the cycle was completed. If the patients presented elevated values of D-dimer $(>20.000 \mathrm{ng} / \mathrm{ml})$, an ultrasound was performed to evaluate the permeability of the catheter. Blood samples were collected before and after each cell infusion, and on days 1,3 , and 7 post-infusion once the infusion cycle was completed. The following parameters were studied: hemoglobin (normal values $11-14.5 \mathrm{~g} / \mathrm{dl}$ ), platelets (normal values $150-350 \times 10^{3} / \mu \mathrm{l}$ ), white blood 
cells (normal values: $4-10 \times 10^{3} / \mu \mathrm{L}$ ), polymorphonuclear $(\mathrm{PMN})$ (normal values $5.6-17 \times 10^{3} / \mu \mathrm{l}$ ), lymphocytes (normal values $1.4-3.8 \times 10^{3} / \mu \mathrm{l}$ ), and monocytes (normal values $0.2-1.3 \times 10^{3} / \mu \mathrm{l}$ ). Hepatic ultrasound and Doppler, to measure the main portal flow (normal values $20-40 \mathrm{~cm} / \mathrm{s}$ [30]) and control the absence of thrombi, were performed before and after each infusion, and on days $1,3,30$, and 90 post-infusion once the infusion cycle was completed. Portal vein pressure (normal values 7-12 mmHg [31]) through a portal catheter was recorded before and every $15 \mathrm{~min}$ during and after the infusions until normalization.

\section{Statistical analysis}

Mixed effects linear regression models were used to assess the impact of time on various outcomes. In each model, the "patient" random effect was included to model the inter-patient variability while the fixed "time" effect was used to assess the increase or decrease of the outcome over time. All statistical analyses were performed using R.3.4.0 and Graphpad 5.0.

\section{Results}

\section{Study population}

Eleven patients were treated with HepaStem infusions, of which five UCD and six CN. Two UCD and two CN patients were assigned to low dose $\left(12.5 \times 10^{6}\right.$ cells $\left./ \mathrm{kg}\right)$, one $\mathrm{UCD}$ and one $\mathrm{CN}$ to medium dose $\left(50 \times 10^{6} \mathrm{cell} / \mathrm{s} / \mathrm{kg}\right)$, and three UCD and two $\mathrm{CN}$ to high dose. The total infusion cycle was administered in 7 patients over 1-4 days in 111 infusions (see Tables 1 and 2). The high dose could not be administered completely to four patients due to catheter displacement $(n=2)$, transfusion reaction $(n=1)$, and high D-dimer levels $>20.000(\mathrm{nl}<500 \mathrm{ng} / \mathrm{ml})$.

\section{Safety}

\section{Thrombogenic risk}

Vital signs stayed in the normal range during and after cell infusions. One OTC patient presented an intraluminal non-occlusive left portal vein thrombus the second day of infusions. Liver ultrasound showed a mild increase in portal vein pressure $(22 \mathrm{mmHg}$-normal value 8-12 mmHg). This was resolved after 1 month with curative low molecular weight heparin treatment. Two other patients presented high portal vein pressure $(>25$ $\mathrm{mmHg}$ ) during cell infusion at the ultrasound. In one patient, the infusion cycle was interrupted for concomitant high D-dimer levels (> $35.000 \mathrm{ng} / \mathrm{ml}$ ) (normal values $<500 \mathrm{ng} / \mathrm{ml}$ ), followed by a fivefold increase in liver enzymes (AST and ALT) 3 days after the infusion cycle was interrupted. They normalized after 14 days without administration of additional anticoagulation treatment. Nevertheless, only a minor, non-significant and clinically non-relevant increase in portal vein pressure has been observed before and after infusions in the whole population of the study (see Fig. 1). Intraportal HepaStem infusion affected the following blood parameters (see Fig. 2 and Table 3).

\section{Difference in blood parameters before and after the infusion and evolution each day till 7 days after the infusion by mixed effects linear regression models, results shown are means, confidence interval 95\% (Cl 95\%), and $p$ values}

D-dimers increased significantly with 1442\% (C195\% $508-3810 \% ; p<0.001)$ between the beginning and the end of the infusion cycle. After the infusions, D-dimers decreased significantly with $31 \%$ per day (CI95\% $24-$ $38 \% ; p<0.001)$ to return to normal levels 7 days after the whole cycle was completed. Hemoglobin (normal values $11-14.5 \mathrm{~g} / \mathrm{dl}$ ) decreased significantly with $1.3 \mathrm{~g} / \mathrm{dl}$ (CI95\% $0.7-1.8 \mathrm{~g} / \mathrm{dl} ; p<0.001)$ after infusion, but increased again significantly with $0.06 \mathrm{~g} / \mathrm{dl}$ per day (CI95\% $0.005-0.1 \mathrm{~g} / \mathrm{dl} ; p=0.03)$ during 7 days after the infusion. Platelets (normal values $150-350 \times 10^{3} / \mu \mathrm{l}$ ) decreased significantly with $77 \times 10^{3} / \mu \mathrm{l}\left(\mathrm{CI} 95 \% 40-114 \times 10^{3} / \mu \mathrm{l} ; p<\right.$ 0.001 ) due to the infusions, but normalized 7 days after the whole cycle was completed by increasing

Table 2 Thrombogenic risk

\begin{tabular}{|c|c|c|c|c|c|}
\hline & Total patients & $\%$ of the total population & $12.5 \times 10^{6} / \mathrm{kg}$ & $50 \times 10^{6} / \mathrm{kg}$ & $200 \times 10^{6} / \mathrm{kg}$ \\
\hline Complication related to anticoagulation & 4 & 36 & & & \\
\hline Hemorrhage at catheter & 1 & 9 & - & - & 1 \\
\hline Epistaxis & 2 & 18 & 1 & 1 & - \\
\hline Petechiae & 1 & 9 & - & - & 1 \\
\hline Procoagulant events & 1 & 9 & & & \\
\hline Portal thrombi & 1 & 9 & - & 1 & - \\
\hline Prematurely stopped infusion cycles & 4 & 36 & & & \\
\hline Catheter problems & 2 & 18 & - & - & 2 \\
\hline Transfusional reaction & 1 & 9 & - & & 1 \\
\hline High D-dimer levels & 1 & 9 & & & 1 \\
\hline
\end{tabular}



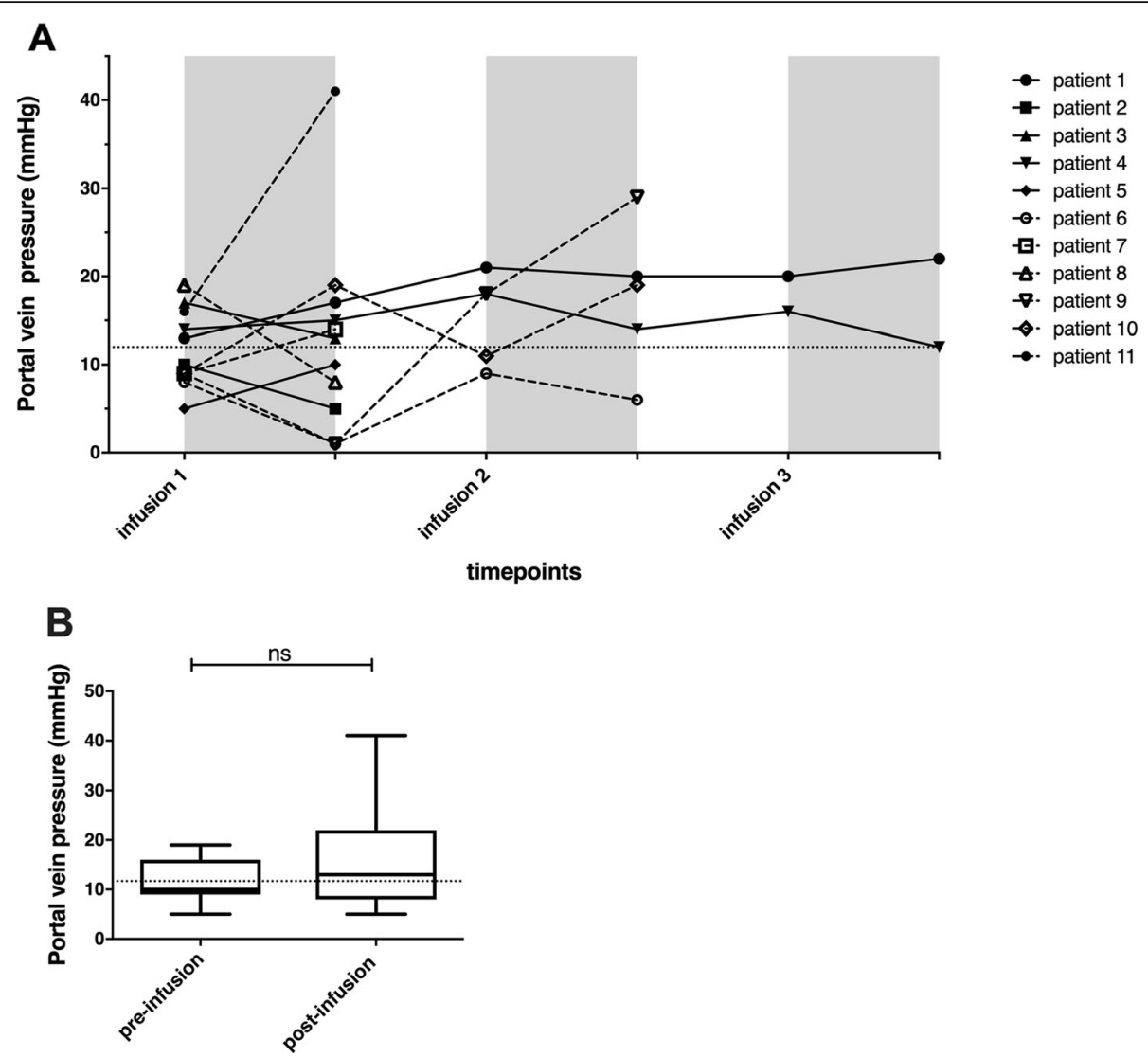

Fig. 1 Monitoring of portal vein pressure before and after intraportal infusion of HepaStem in patients $(n=11)$. Portal vein pressure was monitored through a portal catheter before and every 15 min during and after the infusions until normalization. a Portal vein pressure is represented for each patient during 1, 2, or 3 days of HepaStem infusions. The horizontal dotted line is the maximum normal value. $\mathbf{b} 95 \% \mathrm{Cl}$ (confidence interval) whiskers representing portal vein pressure for all patients at different time points. Statistical analysis: Wilcoxon signed-rank test. The horizontal dotted line represents the mean before infusion. ${ }^{*} p<0.05 ;{ }^{* *} p<0.01$; ${ }^{* * *} p<0.001$

significantly with $15 \times 10^{3} / \mu \mathrm{l}\left(\mathrm{CI} 95 \% 8-22 \times 10^{3} / \mu \mathrm{l} ; p<\right.$ 0.01 ) daily. Total white blood counts (normal value 4$10 \times 10^{3} / \mu \mathrm{L}$ ) increased significantly with $2.7 \times 10^{3} / \mu \mathrm{l}$ (CI95\% $0.6-4.8 \times 10^{3} / \mu \mathrm{l} ; p=0.02$ ) so did PMN (normal value $\left.5.6-17 \times 10^{3} / \mu \mathrm{l}\right)$ with $150 \%(\mathrm{CI} 95 \% 61-288 \% ; p<$ $0.001)$ during cell infusions. Once the whole cycle was completed, PMN and total white blood count normalized after 7 days. No significant difference due to cell infusions has been observed for monocytes.

\section{Hemorrhagic risk}

Anticoagulation was monitored by repeated ACT measurements, remaining in the targeted range (200-350 s) for 8 patients (see Fig. 3). In the other 3 patients, bivalirudin administration had to be reduced until ACT levels decreased beneath $350 \mathrm{~s}$. No major adverse effects were caused by the use of anticoagulant treatment. Four patients, including one patient with too elevated ACT levels, presented minor adverse effects. One patient presented petechiae $24 \mathrm{~h}$ after the infusion, not associated with thrombopenia. Two patients presented epistaxis, of which one during infusion with high ACT levels, resolving once bivalirudin doses were reduced. Finally, one patient presented a minor hemorrhage at the entrance site of the catheter, resolving without sequelae.

\section{Discussion}

In this phase $1 / 2$ clinical study, patients with urea cycle disorders (UCD) and Crigler-Najjar (CN) syndrome were treated with three different cell doses: low $\left(12.5 \times 10^{6}\right.$ cells $/ \mathrm{kg})$, intermediate $\left(50 \times 10^{6}\right.$ cells $\left./ \mathrm{kg}\right)$, and high $\left(200 \times 10^{6}\right.$ cells $\left./ \mathrm{kg}\right)$. This study reports that intraportal HepaStem infusion while using an anticoagulant cocktail, heparin (10 I.U./5 $\times 10^{6}$ cells), and bivalirudin (1.75 $\mathrm{mg} / \mathrm{kg} / \mathrm{h}$ ) is safe. Nevertheless, minor adverse effects were observed. One patient developed a partial left portal vein thrombosis the second day of infusions, causing a mild increase in portal vein pressure, suggesting that cell infusion induced a thrombus only at the infusion site. Two other patients developed high portal vein pressure. One of them presented high D-dimer levels, causing the interruption of the infusion cycle. D-dimers 


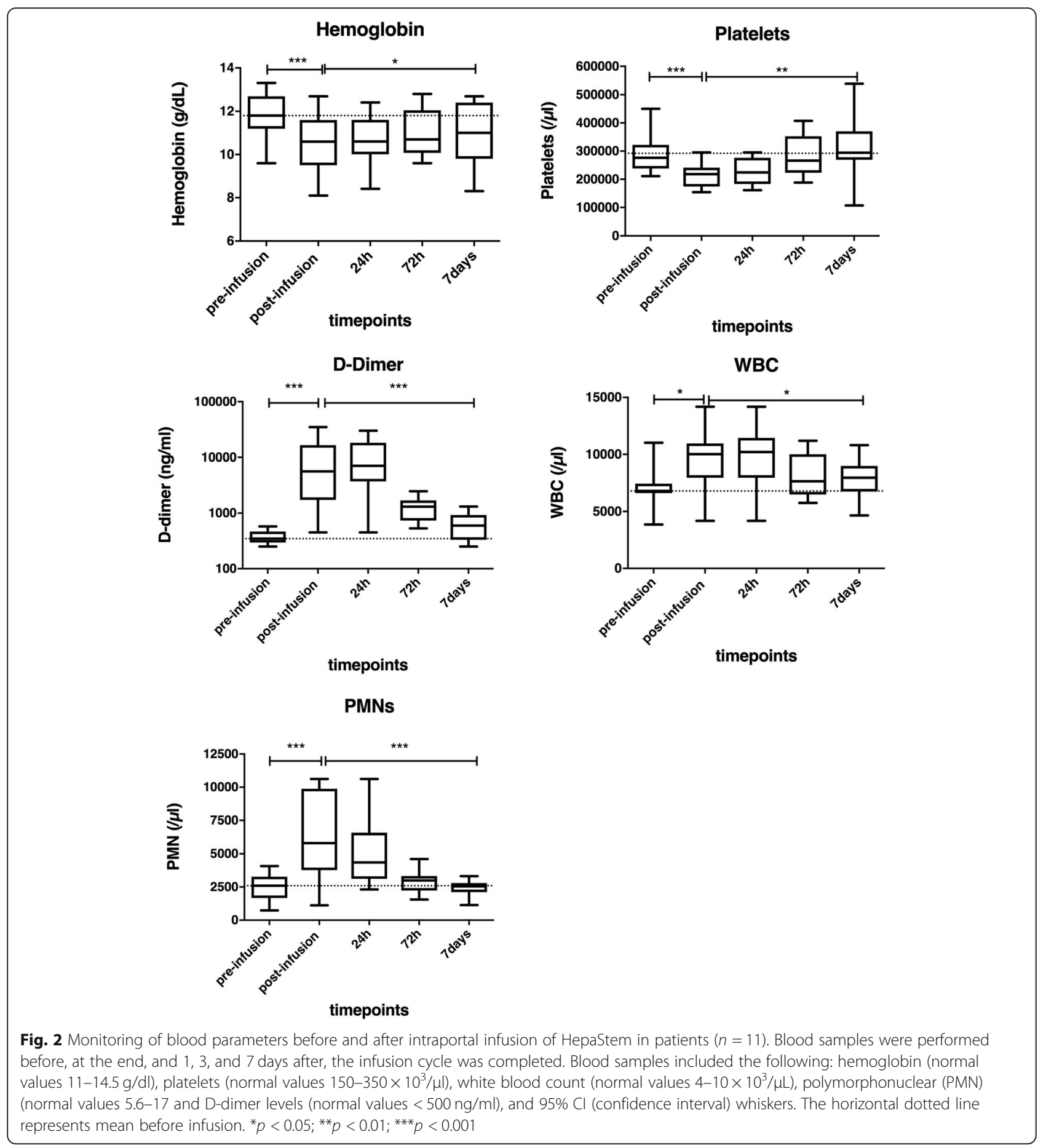

normalized spontaneously after 7 days in all patients, except for the patient who presented partial portal thrombosis who was treated with curative low molecular weight heparin. Portal vein flow could not be analyzed because this parameter results from a delicate equilibrium, influenced by multiple factors such as intraportal cell infusion rate, ingestion of food, or hydration status. These influencing factors were different for all patients, so no analysis could be performed on portal vein flow. Thrombogenic adverse effects seem to be cell-dose dependent. Even though D-dimer levels increased significantly in all patients, abnormal portal pressure was only present in the high-dose group, except for one patient who presented a left portal thrombus after 4 cell infusions in the intermediate group. Cell infusions caused in all patients a significant decrease in 
Table 3 Evolution of blood parameters

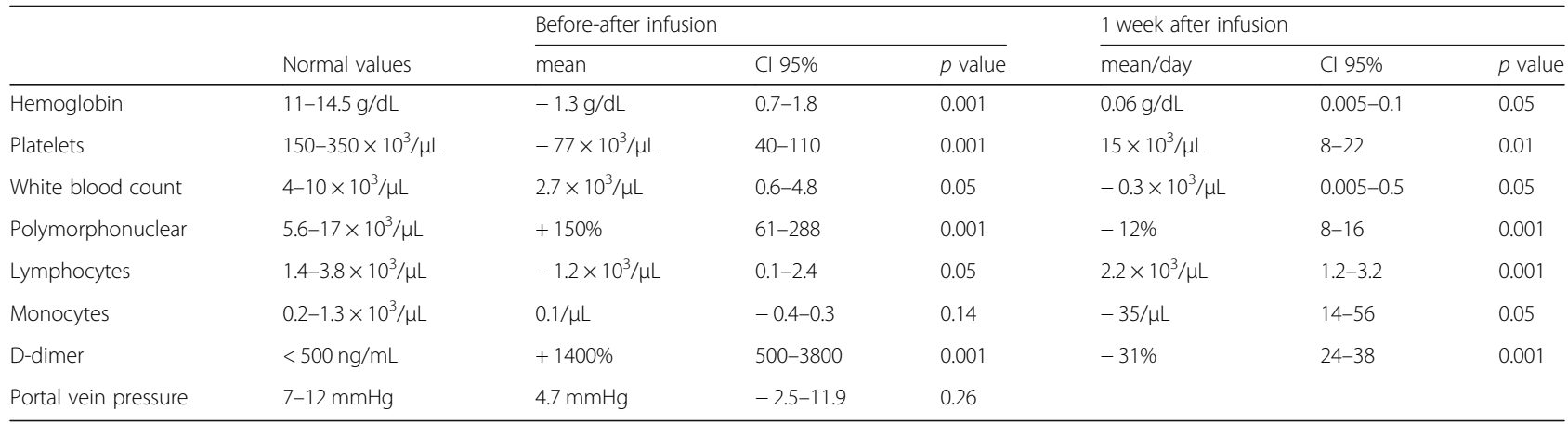

hemoglobin and platelets, but they both normalized after 7 days once the whole cycle was completed. D-dimer levels increased significantly at the end of the infusion cycle but normalized spontaneously 7 days after the whole cycle was completed. This suggests that HepaStem activated the coagulation cascade, with the consumption of platelets and production of fibrin, inducing increased levels of D-dimers. But once the infusing cycle was completed, both parameters normalized spontaneously. Patients with CN or UCD do not express coagulation disorders linked to their disease. Total white blood counts and PMNs significantly increased during cell infusions, in contrary to lymphocytes. Again, all parameters normalized spontaneously after 7 days. No coagulation disorders are described in the literature in patients with $\mathrm{CN}$ or UCD.
A phase $1 \mathrm{~b} / 2 \mathrm{a}$ clinical study by Melmed et al. [20] could confirm this hypothesis. Melmed et al. infused human placenta-derived mesenchymal-like cells to treat moderate to severe Crohn's disease using different cell dosages $\left(1.5-6-12 \times 10^{8}\right.$ cells, corresponding to $2.5-10$ and $20 \times 10^{6} \mathrm{cells} / \mathrm{kg}$ for a patient weighting $60 \mathrm{~kg}$ ). More side effects including venous thrombosis at infusion site were observed in the higher doses of cells. But even at low cell doses $\left(1 \times 10^{6} / \mathrm{kg}\right)$, Wu et al. [19] reported venous thrombosis after intravenous umbilical cord MSC infusions in 2 renal transplanted patients with chronical kidney failure. Both thrombi were distant from the puncture site and associated with an elevation in D-dimer levels. Cell therapy is mainly administered by peripheral intravenous infusions like the two previously cited studies. Johansson et al. [32] nevertheless transplanted by

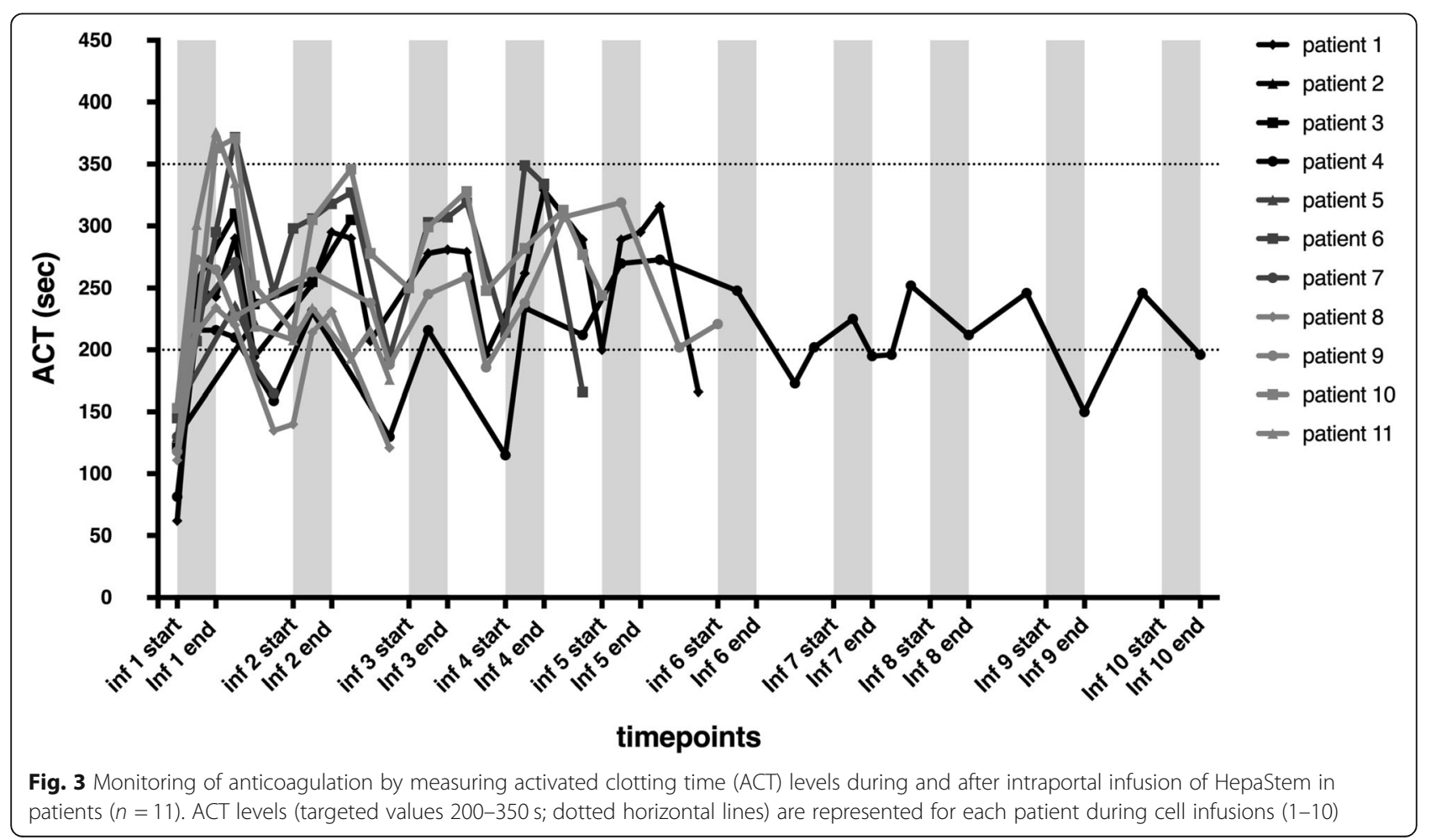


intraportal infusion-isolated human pancreas islets, expressing high levels of tissue factor (TF) like MSCs. All nine patients presented a significant increase in D-dimer levels and in thrombin generation marker thrombinantithrombin (TAT). TAT levels normalized after 1 day, but D-dimer decreased slower. Others [21] studied whether co-transplantation of ex vivo expanded autologous bone marrow-derived mesenchymal stem cells (MSCs) with islets is safe. Portal vein thrombosis (PVT) was present in 2 out of 3 patients after infusion. Based on historical control patients, they showed that patients presenting PVT were transplanted with islet pellets with a higher average weight. These studies show that the infusion site does not influence the activation of coagulation, but once the TF-bearing cell is in contact with blood coagulation starts. Numerous studies [13, 16, 33, 34] showed that the procoagulant activity (PCA) of MSCs is directly linked with the amount of TF expressed by the cells. Some researchers exploit even the PCA of MSCs and use them to treat hemorrhagic diseases. Moll et al. [13, 33] infused human bone marrow-derived MSC and placenta-derived decidual stromal cells (DSC) using low cell doses $\left(1-3 \times 10^{6}\right.$ cells $\left./ \mathrm{kg}\right)$ by peripheral intravenous catheter. The aim was to treat patients with severe complications, such as hemorrhages due to graft-versushost disease and hemorrhagic cystitis after allogeneic hematopoietic stem cell transplantation. The infusion of BMMSC induced a weak but significant drop in platelet counts, with a fivefold increase in TAT. Nevertheless, other blood markers, such as leukocytes, neutrophils, and D-dimer did not change significantly. DSC infusions on the contrary induced a significant increase in Ddimers, which normalized after $24 \mathrm{~h}$, but no significant change in platelets. A study in 2017 [35], where heparin (60-300 I.U.) was infused before and after DSC infusions, did not show any significant change in platelets, thrombogenic adverse effect, or hemorrhages between the DSC infused and control group. In our study, anticoagulation was monitored during cell infusions with repetitive measurements of ACT. ACT levels stayed in the optimal range for almost all patients, except for 3 of them with rapid normalization of ACT levels by reduction of bivalirudin dosage. No major adverse effects were observed while using the anticoagulant cocktail. No patients hemorrhaged when the percutaneous catheter was removed. One patient, with normal ACT levels, presented a minor hemorrhage at the insertion site of the catheter after the third infusion. This was probably due to the movement of the catheter, which moved out of the portal vein, causing a premature stop of the infusion cycle. Two patients, one with high ACT levels, presented epistaxis that stopped rapidly once bivalirudin therapy was decreased. The other patients presented epistaxis in the week following the infusion that resolved spontaneously, probably due to a pre-existing condition. Finally, one patient presented moderate petechiae, without thrombocytopenia, $24 \mathrm{~h}$ after the complete cell cycle, which resolved spontaneously without sequelae. ACT levels stayed in the optimal range for 3 out of 4 patients presenting hemorrhagic events. These minor adverse effects are thus unlikely caused by the use of our anticoagulant drugs.

This study shows that intraportal infusion of HepaStem with the use of an anticoagulant cocktail, bivalirudin, and heparin is safe. The thrombogenic risk caused by these infusions seems to be cell dose-dependent, with a higher risk if a high cell dosage is used. Only minor hemorrhagic adverse effects were observed, and just one seemed related to the use of anticoagulation drugs. Nevertheless, our data suggests that PCA of HepaStem, like other MSCs, still induces activation of coagulation in recipient patients, even if anticoagulation is well controlled. Due to the small number of patients in each group, no statistical analysis could be performed to analyze if cell dosage induces a significant difference in the activation of the coagulation cascade. Further studies with larger cohorts are needed to answer this question.

\section{Conclusion}

Thrombogenic risk induced by MSC infusion is still a concern in cell-based therapy. Our study used a combination of anticoagulant drugs, heparin, and bivalirudin, to control the thrombogenic risk during cell infusions in 11 patients. Even if our data suggests an activation of the coagulation cascade in these patients with anticoagulant drugs, this was spontaneously reversible in time and showed no deleterious effect on hepatic function. We conclude that using heparin and bivalirudin during HepaStem infusion is safe.

\section{Supplementary information}

Supplementary information accompanies this paper at https://doi.org/10. 1186/s13287-020-1572-7.

Additional file 1. Consort flow diagram of the studied population.

\section{Abbreviations}

ACT: Activated clotting time; ALT: Alanine aminotransferase; AST: Aspartate aminotransferase; CN: Crigler-Najjar; DMSO: Dimethyl sulfoxide; DSC: Decidual stromal cells; IBMIR: Instant blood-mediated inflammatory reaction; MSC: Mesenchymal stem cell; OLT: Orthotopic liver transplantation; OTC: Ornithine transcarbamylase; PCA: Procoagulant activity; PMN: Polymorphonuclear; PVT: Portal vein thrombosis; TAT: Thrombinantithrombin; TF: Tissue factor; UCD: Urea cycle disorder

\section{Acknowledgements \\ N/A}

Authors' contributions

ES, FS, and XS contributed to the conception of the work. LC and XS analyzed and interpreted the results. JA performed the statistical analyses. LC 
and XS wrote the manuscript. All authors read and approved the final manuscript.

\section{Funding}

This work was supported by grants from the Fondation Saint-Luc (mandat de recherche temps plein) and from the Fonds National de la Recherche Scientifique et Médicale (FNRS, Belgium) with a FRIA fellowship (F 3/5/5 FRIA/FC).

\section{Availability of data and materials}

The datasets used and/or analyzed during the current study are available from the corresponding author on reasonable request.

\section{Ethics approval and consent to participate}

Ethical approval to report this case series was obtained from Belgian regulatory authorities and the ethical committee (2011/04OCT/388). All procedures in this study were conducted in accordance with the European Medicines Agency's (EMA) pediatric committee (EudraCT number: 2011 004074-28) and conducted according to the 2000 revised principles of the Declaration of Helsinki (ClinicalTrials.gov identifier: NCT01765283). Written informed consent was obtained from a legally authorized representative(s) for anonymized patient information to be published in this article.

\section{Consent for publication}

Written informed consent was obtained from a legally authorized representative(s) for anonymized patient information to participate in this study.

\section{Competing interests}

E.S is a founder and scientific advisor for the Promethera Biosciences and has founding shares and/or stock options. F.S. is the principal Investigator for the Promethera Biosciences. X.S. has a consultancy agreement with the Promethera Biosciences. This study was supported in part by research funding from the Promethera Biosciences. Other authors declare that they have no competing financial interests. All authors declare to have no nonfinancial conflict of interests.

\section{Author details}

${ }^{1}$ Service de Gastro-Entérologie et Hépatologie Pédiatrique, Cliniques Universitaires Saint-Luc, Université Catholique de Louvain, Av Hippocrate 10, B-1200 Brussels, Belgium. ${ }^{2}$ Institut de Recherche Expérimentale et Clinique, Université Catholique de Louvain, Brussels, Belgium.

\section{Received: 27 October 2019 Revised: 17 December 2019} Accepted: 26 January 2020 Published online: 07 February 2020

\section{References}

1. Fisher RA, Strom SC. Human hepatocyte transplantation: worldwide results, Transplantation. 2006;82(4):441-9.

2. Fox IJ, Chowdhury JR, Kaufman SS, Goertzen TC, Chowdhury NR, Warkentin $\mathrm{Pl}$, et al. Treatment of the Crigler-Najjar syndrome type I with hepatocyte transplantation. N Engl J Med. 1998;338(20):1422-6.

3. Muraca M, Gerunda G, Neri D, Vilei MT, Granato A, Feltracco P, et al. Hepatocyte transplantation as a treatment for glycogen storage disease type 1a. Lancet. 2002;359(9303):317-8.

4. Sokal EM, Smets F, Bourgois A, Van Maldergem L, Buts JP, Reding R, et al. Hepatocyte transplantation in a 4-year-old girl with peroxisomal biogenesis disease: technique, safety, and metabolic follow-up. Transplantation. 2003; 76(4):735-8.

5. Stephenne X, Najimi M, Smets F, Reding R, de Ville de Goyet J, Sokal EM. Cryopreserved liver cell transplantation controls ornithine transcarbamylase deficient patient while awaiting liver transplantation. Am J Transplant Off J Am Soc Transplant Am Soc Transplant Surg. 2005;5(8):2058-61.

6. Schneider A, Attaran M, Meier PN, Strassburg C, Manns MP, Ott M, et al. Hepatocyte transplantation in an acute liver failure due to mushroom poisoning. Transplantation. 2006;82(8):1115-6.

7. Dhawan A, Strom SC, Sokal E, Fox IJ. Human hepatocyte transplantation. Methods Mol Biol. 2010;640:525-34

8. Stephenne X, Najimi M, Ngoc DK, Smets F, Hue L, Guigas B, et al. Cryopreservation of human hepatocytes alters the mitochondrial respiratory chain complex 1. Cell Transplant. 2007;16(4):409-19.
9. Stephenne X, Najimi M, Sokal EM. Hepatocyte cryopreservation: is it time to change the strategy? World J Gastroenterol. 2010;16(1):1-14.

10. Sokal EM. From hepatocytes to stem and progenitor cells for liver regenerative medicine: advances and clinical perspectives. Cell Prolif. 2011; 44(Suppl 1):39-43.

11. Barry FP, Murphy JM. Mesenchymal stem cells: clinical applications and biological characterization. Int J Biochem Cell Biol. 2004;36(4):568-84.

12. Stephenne $X$, Nicastro E, Eeckhoudt S, Hermans C, Nyabi O, Lombard C, et al. Bivalirudin in combination with heparin to control mesenchymal cell procoagulant activity. PLoS One. 2012;7(8):e42819.

13. Moll G, Ignatowicz L, Catar R, Luecht C, Sadeghi B, Hamad O, et al. Different procoagulant activity of therapeutic mesenchymal stromal cells derived from bone marrow and placental decidua. Stem Cells Dev. 2015;24(19): 2269-79.

14. Gleeson BM, Martin K, Ali MT, Kumar AH, Pillai MG, Kumar SP, et al. Bone marrow-derived mesenchymal stem cells have innate procoagulant activity and cause microvascular obstruction following intracoronary delivery: amelioration by antithrombin therapy. Stem Cells. 2015;33(9):2726-37.

15. Tatsumi K, Ohashi K, Matsubara Y, Kohori A, Ohno T, Kakidachi H, et al. Tissue factor triggers procoagulation in transplanted mesenchymal stem cells leading to thromboembolism. Biochem Biophys Res Commun. 2013; 431(2):203-9.

16. Christy BA, Herzig MC, Montgomery RK, Delavan C, Bynum JA, Reddoch KM, et al. Procoagulant activity of human mesenchymal stem cells. J Trauma Acute Care Surgery. 2017;83(1 Suppl 1):S164-s9.

17. Sokal EM, Stephenne X, Ottolenghi C, Jazouli N, Clapuyt P, Lacaille F, et al. Liver engraftment and repopulation by in vitro expanded adult derived human liver stem cells in a child with ornithine carbamoyltransferase deficiency. JIMD reports. 2014;13:65-72.

18. Jung JW, Kwon M, Choi JC, Shin JW, Park IW, Choi BW, et al. Familial occurrence of pulmonary embolism after intravenous, adipose tissuederived stem cell therapy. Yonsei Med J. 2013;54(5):1293-6.

19. Wu Z, Zhang S, Zhou L, Cai J, Tan J, Gao X, et al. Thromboembolism induced by umbilical cord mesenchymal stem cell infusion: a report of two cases and literature review. Transplant Proc. 2017;49(7):1656-8.

20. Melmed GY, Pandak WM, Casey K, Abraham B, Valentine J, Schwartz D, et al. Human placenta-derived cells (PDA-001) for the treatment of moderate-to-severe Crohn's disease: a phase 1b/2a study. Inflamm Bowel Dis. 2015;21(8):1809-16.

21. Wang H, Strange C, Nietert PJ, Wang J, Turnbull TL, Cloud C, et al. Autologous mesenchymal stem cell and islet motransplantation: safety and efficacy. Stem Cells Transl Med. 2018;7(1):11-9.

22. Perlee D, van Vught LA, Scicluna BP, Maag A, Lutter R, Kemper EM, et al. Intravenous infusion of human adipose mesenchymal stem cells modifies the host response to lipopolysaccharide in humans: a randomized, single-blind, parallel group, placebo controlled Trial. Stem Cells. 2018;36(11):1778-88.

23. Bennet W, Groth CG, Larsson R, Nilsson B, Korsgren O. Isolated human islets trigger an instant blood mediated inflammatory reaction: implications for intraportal islet transplantation as a treatment for patients with type 1 diabetes. Ups J Med Sci. 2000;105(2):125-33.

24. Moberg L, Johansson H, Lukinius A, Berne C, Foss A, Kallen R, et al. Production of tissue factor by pancreatic islet cells as a trigger of detrimental thrombotic reactions in clinical islet transplantation. Lancet. 2002;360(9350):2039-45.

25. Gustafson EK, Elgue G, Hughes RD, Mitry RR, Sanchez J, Haglund U, et al. The instant blood-mediated inflammatory reaction characterized in hepatocyte transplantation. Transplantation. 2011;91(6):632-8.

26. Lee CA, Dhawan A, Smith RA, Mitry RR, Fitzpatrick E. Instant blood-mediated inflammatory reaction in hepatocyte transplantation: current status and future perspectives. Cell Transplant. 2016;25(7):1227-36.

27. Nilsson B, Ekdahl KN, Korsgren O. Control of instant blood-mediated inflammatory reaction to improve islets of Langerhans engraftment. Curr Opin Organ Transplant. 2011;16(6):620-6.

28. Smets F, Dobbelaere D, McKiernan P, Dionisi-Vici C, Broue P, Jacquemin E, et al. Phase I/II trial of liver derived mesenchymal stem cells in pediatric liver based metabolic disorders: a prospective, open label, multicenter, partially randomized, safety study of one cycle of heterologous human adult liverderived progenitor cells (HepaStem(R)) in urea cycle disorders and CriglerNajjar syndrome patients. Transplantation. 2019;103(9):1903-15.

29. Najimi M, Khuu DN, Lysy PA, Jazouli N, Abarca J, Sempoux C, et al. Adultderived human liver mesenchymal-like cells as a potential progenitor reservoir of hepatocytes? Cell Transplant. 2007;16(7):717-28. 
30. Iranpour P, Lall C, Houshyar R, Helmy M, Yang A, Choi Jl, et al. Altered Doppler flow patterns in cirrhosis patients: an overview. Ultrasonography. 2016;35(1):3-12.

31. Armonis A, Patch D, Burroughs A. Hepatic venous pressure measurement: an old test as a new prognostic marker in cirrhosis? Hepatology. 1997;25(1): 245-8.

32. Johansson H, Lukinius A, Moberg L, Lundgren T, Berne C, Foss A, et al. Tissue factor produced by the endocrine cells of the islets of Langerhans is associated with a negative outcome of clinical islet transplantation. Diabetes. 2005;54(6):1755-62.

33. Moll G, Rasmusson-Duprez I, von Bahr L, Connolly-Andersen AM, Elgue G, Funke $L$, et al. Are therapeutic human mesenchymal stromal cells compatible with human blood? Stem Cells. 2012;30(7):1565-74.

34. Moll G, Alm JJ, Davies LC, von Bahr L, Heldring N, Stenbeck-Funke L, et al. Do cryopreserved mesenchymal stromal cells display impaired immunomodulatory and therapeutic properties? Stem Cells. 2014;32(9): 2430-42.

35. Baygan A, Aronsson-Kurttila W, Moretti G, Tibert B, Dahllof G, Klingspor L, et al. Safety and side effects of using placenta-derived decidual stromal cells for graft-versus-host disease and hemorrhagic cystitis. Front Immunol. 2017; 8:795.

\section{Publisher's Note}

Springer Nature remains neutral with regard to jurisdictional claims in published maps and institutional affiliations.

Ready to submit your research? Choose BMC and benefit from:

- fast, convenient online submission

- thorough peer review by experienced researchers in your field

- rapid publication on acceptance

- support for research data, including large and complex data types

- gold Open Access which fosters wider collaboration and increased citations

- maximum visibility for your research: over $100 \mathrm{M}$ website views per year

At $\mathrm{BMC}$, research is always in progress.

Learn more biomedcentral.com/submissions 